\title{
KRISIS KEUANGAN GLOBAL DAN PERTUMBUHAN EKONOMI: ANALISA DARI PEREKONOMIAN ASIA TIMUR ${ }^{1}$
}

\author{
Arisyi F. Raz ${ }^{2}$, Tamarind P. K. Indra ${ }^{3}$, Dea K. Artikasih ${ }^{4}$, and Syalinda Citra ${ }^{5}$
}

\begin{abstract}
Sejalan dengan semakin terintegrasinya perekonomian di tengah eraglobalisasi, krisis keuangan yang terjadi pada suatu negara dapat dengan mudah menyebar ke negara-negara lain dan menjadi bencana keuangan global dalam kurun waktu yang singkat. Pada kejadian semacam ini, fundamental ekonomi yang kuat sangat penting untuk mempertahankan suatu negara dari efek krisis yang "menular". Sebagai bukti, karena fundamental ekonomi yang rapuh dan kurangnya kredibilitas pemerintah, perekonomian Asia Timur dapat diserang dengan mudah oleh krisis pada tahun 1997 begitu kepercayaan pasarmemburuk. Namun demikian, Asia Timurini telah belajar banyak dari kejadian pada tahun 1997 tersebut sehingga dapat membuktikan ketahanannya dalam menghadapi krisis keuangan global yang melanda pada tahun 2008 dengan meningkatkan fundamental ekonominya serta kredibilitas para pembuat kebijakan. Makalah ini dimulai dengan teori tentang pertumbuhan ekonomi dan krisis keuangan. Selanjutnya, secara empiris menguji sejauh mana krisis keuangan pada tahun 1997 dan 2008 mempengaruhi perekonomian Asia Timur dengan menggunakan data panel ekonometri. Bukti menunjukkan bahwa, meskipun kedua krisis telah memberikan dampak buruk pada perekonomian Asia Timur, gelombang krisis 2008 relatif tidak lebih parah daripada krisis tahun 1997. Akhirnya, penelitian ini juga memberikan penjelasan lebih lanjut tentang bagaimana perekonomian Asia Timur telah berhasil meminimalkan dampak krisis global pada tahun 2008.
\end{abstract}

Kata kunci: Krisis Keuangan Global; Ekonomi Asia Timur, Pertumbuhan Ekonomi, Pasar Finansial, Efek Acak dan Tetap

JEL Classification: C330, E440, G010

\footnotetext{
1 Penulis berterima kasih atas komentar yang sangat bermanfaat dari Andi M. Alfian Parewangi. Versi sebelumnya dari makalah ini dipresentasikan pada the $6^{\text {th }}$ Annual Workshop Bulletin of Monetary Economics and Banking, Jakarta, September 6, 2012.

2 Lulusan Institute for Development Policy and Management, University of Manchester.

3 Mahasiswa pascasarjana Graduate School of Business of Economics, University of Melbourne.

4 Alumni Department of Business and Asian Studies, Griffith University.

5 Mahasiswa pascasarjana Faculty of Economics and Business, University of Indonesia.
} 


\section{PENDAHULUAN}

Sejak era globalisasi, krisis keuangan menjadi lebih sering terjadi daripada sebelumnya. Salah satu alasan utamanya adalah kemajuan dalam teknologi informasi, yang, sampai batas tertentu, memperbesar gelombang krisis dan mempercepat penyebarannya ke daerah atau negara lain. Alasan lain adalah perkembangan pesat dari sektor keuangan. Salah satu contoh adalah munculnya International Financial Integration (IFI). Dalam hal ini, Edison et al. (2002) menjelaskan bahwa IFI mengacu pada "sejauh mana suatu perekonomian tidak membatasi transaksi lintas batas" (halaman 1). Oleh karena itu, karena sistem keuangan yang terintegrasi, timbulnya gangguan keuangan domestik di satu negara dapat mengakibatkan efek domino dengan cara mengacaukan ekonomi terintegrasi lainnya yang mengarah kepada kekacauan keuangan global.

Dalam dua dekade terakhir, setidaknya dua krisis keuangan besar terjadi, yaitu Krisis Keuangan Asia Timur 1997 dan Krisis Keuangan Global 2008. Jika krisis pada tahun 1997 disebabkan oleh kurangnya transparansi dan kredibilitas pemerintah yang menyebabkan distorsi struktural dan kebijakan (lihat contoh Corsetti et al., 1999), gejolak ekonomi tahun 2008 terutama dipicu oleh inovasi yang cepat dalam produk keuangan seperti praktek sekuritisasi dan "credit default swap". Hal ini diperburuk oleh spekulasi properti dan peringkat kredit yang tidak akurat. Pada kedua kasus, perkembangan krisis menyebar ke benua-benualain dan, dalam waktu singkat, menjadi krisis global karena efek menular di tengah sistem keuangan yang terintegrasi secara global dan persebaran informasi yang cepat.

Meskipun sumber krisis dapat bervariasi, konsekuensi dari krisis keuangan selalu dikaitkan dengan indikator makroekonomi, khususnya pertumbuhan ekonomi. Sebagai contoh, selama krisis Asia Timur, pertumbuhan ekonomi Asia Timur jatuh dari wilayah dengan pertumbuhan tercepat di dunia menjadi wilayah yang beberapa negara anggotanya mencatat pertumbuhan pendapatan yang negatif pada tahun 1998 seperti Indonesia, Malaysia, Singapura, Korea Selatan, Filipina dan Thailand (Asian Development Bank, 1999, Tabel A2). Selanjutnya, Indonesia, Thailand dan Korea Selatan harus meminta program pinjaman dana talangan ke Dana Moneter Internasional (IMF). Di sisi lain, selama krisis 2008, meskipun sumber krisis disebabkan oleh runtuhnya lembaga-lembaga keuangan internasional di barat, terutama di Amerika Serikat dan Inggris, beberapa negara Asia Timur seperti Malaysia, Singapura dan Thailand juga diseret ke krisis dengan mengalami pembebanan keuangan besar. Namun demikian, statistik menunjukkan bahwa dampak krisis pada tahun 2008 di negara-negara Asia Timur tidak seburuk pada tahun 1997. Selain itu, negara-negara ini berhasil pulih dengan cepat. Dalam hal ini, banyak yang berpendapat bahwa negara Asia Timur telah belajar banyak pada tahun 1997 dan berhasil menahan krisis pada tahun 2008 melalui fundamental ekonomi yang telah diperkuat.

Dengan melihat fakta ini, pemeriksaan formal penyebab dan konsekuensi vis-à-visthe dari krisis keuangan menjadi semakin penting untuk dilakukan, terutama dalam konteks kawasan Asia Timur. Oleh karena itu, tujuan dari penelitian ini adalah untuk mengukur dampak dari 
setiap krisis keuangan terhadap pertumbuhan ekonomi di negara Asia Timur. Selanjutnya, juga penting untuk menganalisa bagaimana perekonomian Asia Timur berhasil meminimalkan dampak Krisis Keuangan Global tahun 2008. Sampai saat ini, meskipun sudah terdapat banyak literatur yang menganalisa dampak dari Krisis Keuangan Asia Timur 1997, sebagian besar penelitian ini menggunakan pendekatan kualitatif (contoh, lihat Corsetti et al, 1999;. Lloyd dan MacLaren, 2000; Jomo , 2001). Selain itu, karena terjadi baru-baru ini, studi yang meneliti konsekuensi dari Krisis Keuangan Global 2008 juga terbatas. Oleh karena itu, makalah ini bertujuan untuk mengisi kesenjangan dalam literatur dengan memperkenalkan metodologi kuantitatif dan membandingkan konsekuensi dari kedua krisis dalam perekonomian Asia Timur. Selebihnya makalah ini diorganisasikan sebagai berikut: Bagian 2 memberikan ulasan teori terkait pada pertumbuhan ekonomi dan krisis keuangan, Bagian 3 memberikan metodologi untuk mengukur dampak dari kedua krisis keuangan terhadap pertumbuhan dengan menggunakan pemodelan ekonometrik, Bagian 4 menyajikan bukti empiris dan diskusi lebih lanjut, dan Bagian 6 menyimpulkan makalah.

\section{TEORI}

\section{Teori Pertumbuhan}

Karena tujuan dari makalah ini adalah untuk menguji dampak krisis keuangan terhadap pertumbuhan ekonomi, makalah ini perlu terlebih dahulu menjabarkan faktor-faktor pertumbuhan dari perspektif teoritis. Dengan demikian, bagian ini memperkenalkan beberapa teori pertumbuhan ekonomi yang dapat diterapkan untuk tujuan metodologi. Menurut pandangan neoklasik (misalnya Solow, 1956), pertumbuhan didukung oleh akumulasi modal dengan "diminishing rate" dalam jangka panjang. Sebagai konsekuensinya, negara akan mencapai "steady-state" nya dalam jangka panjang, yaitu stagnasi pertumbuhan ekonomi. Salah satu implikasi dari model pertumbuhan ini adalah bahwa negara-negara terbelakang dengan ekonomi terbuka akhirnya dapat mengejar ketertinggalannya darinegara-negara maju sebab modal mengalir dari negara majuke negara terbelakangsehingga dapat menawarkan keuntungan yang lebih tinggi atas investasi, yang mengakibatkan konvergensi ekonomi (Todaro dan Smith, 2006).

Di sisi lain, apa yang disebut dengan "new growth theory" bertentangan dengan teori ini dengan menyatakan bahwa negara tidak selalu mengalami "steady-state" dalam jangka panjang. Misalnya, sebuah penelitian oleh Lucas (1988) yang menganggap bahwa sumber daya manusia sebagai variabel endogen pertumbuhan ekonomi menunjukkan bahwa tidak ada "diminishing return" pada kombinasi dari akumulasi sumber daya manusia dan barang modal.Dengan kata lain ada pertumbuhan dalam jangka panjang. Hasil "constant returns tos cale" ini disebabkan oleh efek eksternalitas positif pengetahuan, yang mempengaruhi output dari masing-masing perusahaan dalam perekonomian. Teori lain diajukan oleh Romer (1986), yang mendesak pentingnya ilmu pengetahuan dan teknologi sebagai mesin pertumbuhan 
ekonomi. Dia berpendapat bahwa terdapat "spillovers" modal yang dibuat oleh perusahaan, yang, pada gilirannya, menciptakan pengetahuan. Pengetahuan memicu eksternalitas positif dan akan mencegah penyusutan pertumbuhan dalam jangka panjang.

Dalam aplikasi, sumber daya manusia dan "spillovers" pengetahuan dapat diperoleh melalui FDI dan, sampai batas tertentu, perdagangan. Dalam lingkup negara berkembang, Yao dan Wei (2007) berpendapat bahwa FDI dapat bertindak sebagai sarana untuk mentransfer faktor-faktor dari negara maju ke negara berkembang karena FDI memperlancar kecepatan "General Purpose Technology ${ }^{6}$ (GPT) dan memperkenalkan teknologi canggih dan ilmu pengetahuan yang tidak ada di negara-negara berkembang. Dengan demikian, negara-negara berkembangakan memanfaatkan faktor-faktor ini sebagai aset dalam rangka meningkatkan pertumbuhan ekonomi. Perlu dipertegas bahwa beberapa literatur menunjukkan bahwa FDI dapat mendistribusikan pengetahuan dan ilmu pengetahuan secara efisien ke suatu negara hanya jika negara tersebut memenuhi beberapa kondisi. Misalnya, sebuah hipotesis oleh Bhagwati (1994) menunjukkan bahwa kebijakan perdagangan memainkan peran penting dalam menentukan efektivitas FDI dalam mendistribusikan eksternalitas positif di suatu negara. Dalam hal ini, ia berpendapat bahwa negara dengan orientasi ekspor dapat menangkap efek "spillovers" FDI lebih efisien dan, dengan demikian, akan memiliki tingkat pertumbuhan yang lebih tinggi.

Singkatnya, bagian ini menunjukkan bahwa, berdasarkan pada teori pertumbuhan neoklasik, pendapatan awal merupakan faktor penting pertumbuhan karena negara-negara dengan pendapatan awal yang relatif rendah akan tumbuh lebih cepat dan mengejar ketinggalan dengan negara-negara yang berpendapatan awal lebih tinggi. Lebih lanjut, hal itu juga menunjukkan bahwa akumulasi modal bertindak sebagai mesin pertumbuhan dalam jangka pendek. Sementara itu, teori-teori pertumbuhan baru menyatakan bahwa variabel seperti FDI dan perdagangan juga penting dalam menciptakan pertumbuhan ekonomi yang berkelanjutan dalam jangka panjang dengan menciptakan eksternalitas positif melalui transfer pengetahuan. Oleh karena itu, untuk tujuan metodologi, variabel-variabel ini dianggap sebagai penentu utama pertumbuhan. Sebelum melanjutkan ke metodologi, makalah ini terlebih dahulu akan menyelidiki tipologi krisis keuangan pada bagian berikut.

\section{Tipologi Krisis Keuangan}

Reserve Bank of Australia (2012) mendefinisikan sebuah sistem keuangan yang stabil sebagai sistem di mana setiap kegiatan transfer dana dari pemberi pinjaman kepada peminjam diakomodasi dengan baik oleh perantara keuangan, pasar, dan struktur pasar. Oleh karena itu, ketidakstabilan keuangan adalah suatu kondisi di mana jatuhnya sistem keuangan karena mengganggu kegiatan-kegiatan ini dan memicu krisis keuangan. Sesungguhnya risiko sistemik

6 General Purpose Technologies merupakan teknologi yang berdampak terhadap perekonomian nasional secara keseluruhan, seperti komputer dan otomobil. 
selalu melekat pada setiap sistem keuangan, yang menurut Davis (2001) berkaitan erat dengan kekayaan dan kesehatan lembaga keuangan. Dalam kasus lain, kegagalan likuiditas pasar dan kerusakan infrastruktur pasar juga dapat menginisiasi risiko.

Dalam makalahnya, Davis (2001) juga menguraikan beberapa kerangka teori yang menjelaskan ketidakstabilan keuangan, yang meliputi: 1) teori debt and financial fragility, 2) teori disaster myopia, and 3) teori bank runs. Teori debt and financial fragility berpendapat bahwa perekonomian mengikuti siklus yang terdiri dari periode pertumbuhan positif dan negatif (Fisher, 1933). Dengan kemajuan ekonomi, utang dan kegiatan pengambilan risiko meningkat. Ini menciptakan gelembung aset yang akan mengarah pada pertumbuhan negatif. Sementara itu, teori disaster myopia menunjukkan bahwa ketidakstabilan keuangan dapat disebabkan oleh perilaku kompetitif lembaga keuangan yang mengarah pada suatu kondisi dimana kredibilitas peminjam diabaikan dan risiko dikurangi (Herring, 1999). Di sisi lain, teori bank runs menjelaskan kondisi di mana para investor yang panik menjual aset mereka atau menarik dana mereka karena takut bahwa kondisi ekonomi akan memburuk (Diamond dan Dybvig, 1983, Davis, 1994). Sebagai konsekuensinya, hal ini akan mengakibatkan kemerosotan yang tibatiba pada harga aset dan krisis likuiditas.

Sejauh batasannya, ketiga teori ini dapat menjelaskan Krisis Keuangan Asia Timur 1997. Deregulasi keuangan dengan pengawasan peraturan yang tidak memadai menyebabkan gelembung aset yang mengakibatkan pertumbuhan ekonomi negatif dalam perekonomian Asia Timur. Sementara itu, ekspansi yang cepat bisa juga dapat menyebabkan krisis kredit karena kredit yang disalurkan sembarangan ke debitar yang pailit dalam rangka meningkatkan profitabilitas. Terakhir tapi tidak kalah penting, ketika investor menyadari bahwa situasi sudah buruk, mereka menarik dana mereka, yang menyebabkan arus keluar modal yang besar.

Selain teori-teori dasar ini, beberapa literatur menunjukkan bahwa ketidakstabilan keuangan juga bisa disebabkan oleh peran arus modal internasional melalui transmisi internasional, seperti pola perdagangan, tekanan nilai tukar dan investasi asing, yang menyebabkan "efek menular" (lihat misalnya Chongvilaivan, 2010; Glock dan Rose, 1998; Davis, 2001). Sebagai contoh, Krisis Keuangan Global yang terjadi pada tahun 2008 sebenarnya dipicu oleh krisis "subprimemortgage"yang bermula di Amerika Serikat. Meskipun krisis di AS dapat dijelaskan oleh teori-teori di atas, penyebarannya ke daerah lain, termasuk kawasan Asia Timur, disebabkan efek menular dari krisis "subprimemortgage".

\section{METODOLOGI PENELITIAN}

Bagian ini menyajikan metodologi penelitian dalam menguji dampak dari krisis keuangan tahun 1998 dan 2008 pada perekonomian Asia Timur. Makalah ini mengumpulkan data set dari World Bank's World Development Indicators (WDI) untuk periode 1990-2010. Didalamnya terdapat berbagai variabel makroekonomi dari perekonomian Asia Timur yang telah dipilih, 
termasuk ASEAN-5 (Indonesia, Malaysia, Filipina, Singapura, dan Thailand) dan perekonomian Asia Timur lainnya seperti China, Jepang dan Korea Selatan.

Untuk menguji hubungan antara pertumbuhan ekonomi dan krisis keuangan, makalah ini perlu untuk mengembangkan faktor-faktor penentu pertumbuhan lebih dulu. Dengan mengikuti studi sebelumnya (misalnya, lihat Barro, 2001, Chongvilaivan, 2010), pertumbuhan ditentukan sebagai fungsi dari pendapatan awal, belanja modal, investasi, dan perdagangan. Kemudian, model pertumbuhan acuan ini ditambahkan dengan Dummy krisis. Sebagai hasilnya, makalah ini mendefinisikan kerangka empiris sebagai berikut:

$$
\text { Growth }_{i t}=\beta_{0}+\beta_{1} \text { Income }_{i t}+\beta_{2} \text { Capital }_{i t}+\beta_{3} \text { FDI }_{i t}+\beta_{4} \text { Trade }_{i t}+\beta_{5} \text { Crisis }_{i t}+\varepsilon
$$

dimana $i, i=1,2, \ldots, N$, and $t, t=1,2, \ldots, T$, menunjukkan ekonomi i pada periode waktu t, berturut-turut.

Variabel dependen, Pertumbuhan, adalah PDB per kapita tingkat pertumbuhan. Variabel penjelas pertama, Pendapatan, adalah bentuk logaritmik dari PDB per kapita. Selanjutnya, Capital adalah pembentukan modal tetap bruto sebagai persentase dari PDB, yang disertakan dalam rangka menlihat tingkat produktivitas negara tertentu (Siegel dan Griliches, 1992, Siegel, 1997). Alasannya adalah, bagian akumulasi modal yang lebih tinggi mengarah kepada tingkat produktivitas yang lebih tinggi, sehingga meningkatkan pertumbuhan pendapatan. FDIadalah investasi langsung asing bersih sebagai persentase dari PDB. Sampai batas tertentu, peran FDI dalam memberikan kontribusi terhadap pertumbuhan bisa serupa dengan modal tetapi tidak terbatas pada itu saja. Alasannya adalah karena FDI juga memfasilitasi eksternalitas dan efek spillover, yang meningkatkan lebih lanjut efisiensi produktivitas perusahaan lokal (misalnya, lihat Lim, 2001; Yao dan Wei, 2007). Perdagangan mewakili keterbukaan perdagangan internasional, yang diukur dengan rasio ekspor dan impor terhadap PDB. Chongvilaivan (2010) menunjukkan bahwa variabel ini mewakili dampak dari krisis keuangan global terhadap perekonomian sehubungan dengan pasar komoditas. Akhirnya, variabel dummy krisis dimasukkan dalam model. Dummy ini bernilai satu selama periode krisis, seperti pada Krisis Keuangan Asia Timur 1998 dan Krisis Keuangan Global 2008, dan nol sebaliknya. Untuk rincian lebih lanjut tentang variabel, silakan lihat Lampiran 1.

Dari model ini, pendapatan diperkirakan akan memiliki tanda negatif. Alasan ini didasarkan pada model neo-klasik Swan Solow, yang menunjukkan bahwa perekonomian dengan tingkat pendapatan yang lebih rendah akan tumbuh lebih cepat dan mengejar perekonomian dengan tingkat pendapatan yang lebih tinggi, sehingga mengakibatkan konvergensi pendapatan (misalnya, lihat Solow, 1956). Sebaliknya, modal dan FDI diperkirakan memiliki hubungan positif dengan pertumbuhan. Sementara model neo-klasik Solow-Swan menyatakan bahwa semua jenis modal memiliki peran yang sama dalam memberikan kontribusi terhadap pertumbuhan ekonomi, " new growth theory" menyatakan sebaliknya. Seperti yang disebutkan sebelumnya, melalui FDI, eksternalitas-eksternalitas ini dapat ditransfer dari negara-negara industri ke negara- 
negara berkembang sebagai aset penting untuk meningkatkan pertumbuhan ekonomi lebih lanjut (misalnya, lihat Yao dan Wei, 2007). Karena alasan ini, makalah ini memperkirakan koefisien FDI menjadi lebih besar dibandingkan dengan modal karena memiliki peran yang lebih besar dalam memberikan kontribusi terhadap pertumbuhan ekonomi.

Hubungan antara keterbukaan perdagangan dan pertumbuhan pendapatan bisa lebih kompleks dan tergantung pada apakah perdagangan internasional menyebabkan penciptaan perdagangan atau pengalihan perdagangan. Yang pertama terjadi ketika perdagangan internasional meningkatkan kesejahteraan para anggota aliansi perdagangan tanpa mengorbankan non-anggota. Sebaliknya, yang keduaterjadi ketika aliansi perdagangan terbentuk dengan mengorbankan non-anggota dan dengan demikian kesejahteraan menurun. Dalam hal ini, hubungan antara keterbukaan perdagangan dan pertumbuhan pendapatan tergantung pada pengaruh mana yang memiliki efek yang lebih kuat.

Terakhir, koefisien Dummy krisis diperkirakan negatif karena bersifat intuitif. Namun demikian, koefisien Krisis Keuangan Asia Timur tahun 1998 diperkirakan akan lebih besar daripada koefisien Krisis Keuangan Global tahun 2008 karena, seperti yang disebutkan sebelumnya, negara-negara Asia Timur telah memiliki fundamental yang lebih kuat dan ketahanan yang lebih baik selama Krisis Keuangan Global 2008.

Karena sifat panel data, makalah ini menggunakan metode fixed effects dan random effects untuk tujuan estimasi. Dengan menggunakan fixed effects, model mengontrol heterogenitas yang tak teramati dengan mengasumsikan bahwa setiap negara memiliki efeknya sendiri yang dapat mempengaruhi variabel dependen. Pada model ini, heterogenitas masingmasing negara ditangkap oleh intercept dan dihubungkan dengan variabel independen. Dengan demikian, sifat alamiah fixed effects mencegah adanya bias heterogen dalam estimasi dan dengan demikian model ini selalu memberikan hasil-hasil yang konsisten. Keberadaan fixed effects dapat diuji dengan melakukan F-test. Fixed effects signifikan ketika nol secara signifikan ditolak. Model lainnya adalah model random effects yang mengasumsikan bahwa variasi di seluruh negara adalah acak dan tidak berkorelasi dengan variabel independen. Berbeda dengan model fixed effects, keberadaan random effects dapat diuji dengan menggunakan tes BreuschPagan Lagrange Multiplier.

\section{HASIL DAN ANALISA}

Bagian ini menyajikan hasil estimasi dari persamaan (1). Namun demikian, sebelum melanjutkan ke hasil, perlu untuk membenarkan stasioneritas dari variabel-variabel yang disertakan dalam model. Seperti yang ditunjukkan sebelumnya, penelitian ini menggunakan set data yang mencakup periode yang panjang, yaitu 21 tahun. Jadi beberapa variabel mungkin mengandung akar unit. Jika akar uni hadir, variabel-variabel ini menjadi non-stasioner dan menyebabkan metode estimasi tradicional (OLS) tidak dapat digunakan karena dapat 
menghasilkan regresi spurious. Dalam hal ini, tes untuk kointegrasi diperlukan untuk variabelvariabel non-stasioner.

Terdapat beberapa tes panel akar unit yang dapat dilakukan seperti Hadri (2000), Levin, dan Lin Chu (2002) dan Im, Pesaran dan Shin (2003). Makalah ini menggunakan Levin, Lin dan Chu (2002) untuk menguji keberadaan akar unit dalam variabel. Hasil menunjukkan bahwa stasioneritas variabel-variabel ini adalahnol sehingga keberadaan unit akar secara signifikan ditolak pada tingkat 5\% untuk semua variabel (Lampiran 4). Oleh karena itu tidak perlu melakukan uji kointegrasi. Sehingga, Persamaan (1) dapat diperkirakan dengan menggunakan model fixed effects dan random effects.

Selain itu, karena sifat dari data, korelasi serial dan/atau heteroskedastisitas dapat timbul, sehingga dapat menyebabkan hasil estimasi yang tidak konsisten dan bias. Oleh karena itu, makalah ini mengoreksi masalah ini dengan memperlakukan setiap negara sebagai cluster untuk memperkirakan kesalahan standar yang benar dengan Huber/White cluster-robust covariance estimator dalam semua regresi.

\section{Regresi Pertumbuhan Acuan}

Kolom pertama dari Tabel 1 menunjukkan hasil estimasi fixed effects, sedangkan kolom kedua menunjukkan hasil estimasi random effects. Secara keseluruhan, hasilnya konsisten dengan teori ekonomi dan ekspektasi. Variabel penjelas pertama, pendapatan, tidak signifikan dalam kolom pertama, tetapi signifikan pada 1\% pada kolom kedua dengan koefisien negatif.

Selanjutnya, modal signifikan dalam kedua kolom, meskipun koefisiennyalebih besar dalam random effects. Secara keseluruhan, meskipun besarnya relatif lebih tinggi, hasil ini konsisten dengan penelitian sebelumnya (misalnya, lihat Chongvilaivan, 2010). Oleh karena itu, hal ini membuktikan bahwa akumulasi modal yang lebih tinggi menyebabkan produktivitas yang lebih tinggi dan meningkatkan pertumbuhan pendapatan. Selain itu, FDI juga signifikan pada $1 \%$ dan berkorelasi positif dengan pertumbuhan pendapatan di kedua regresi. Dalam model fixed effects, sesuai dengan perkiraan, koefisienFDI lebih besar dari modal, yang juga konsisten dengan penelitian sebelumnya (misalnya, lihat Stopford et al, 1991; Azman-Saini dan Ahmad, 2010). Namun, berlawanan dengan hasil dalam model fixed effects, model random effects menunjukkan bahwa koefisien modal sedikit lebih tinggi dari FDI.

Terakhir, perdagangan memiliki tanda negatif dan hanya signifikan pada random effects.Bukti yang lemah dari hubungan antara keterbukaan perdagangan dan pertumbuhan pendapatan mungkin ditujukan pada keberadaanpenciptaan dan pengalihandagang (Viner, 1950). Apabila efek pengalihan dagang dalam suatu wilayah lebih besar dari penciptaannya, keterbukaan perdagangan tidak akan berakibat pada perkembangan output. 


\begin{tabular}{|c|c|c|}
\hline \multicolumn{3}{|c|}{$\begin{array}{l}\text { Tabel } 1 . \\
\text { Regresi Pertumbuhan Acuan }\end{array}$} \\
\hline Variabel & Fixed effects & Random effects \\
\hline Konstan & $\begin{array}{c}-14.575 \\
(6.982)\end{array}$ & $\begin{array}{l}-1.206 \\
(2.158)\end{array}$ \\
\hline Pendapatan & $\begin{array}{c}3.098 \\
(2.141)\end{array}$ & $\begin{array}{l}-1.274^{* * *} \\
(0.417)\end{array}$ \\
\hline Modal & $\begin{array}{l}0.216^{* *} \\
(0.068)\end{array}$ & $\begin{array}{l}0.310^{* * *} \\
(0.050)\end{array}$ \\
\hline FDI & $\begin{array}{l}0.417^{* * *} \\
(0.100)\end{array}$ & $\begin{array}{l}0.202^{* * *} \\
(0.054)\end{array}$ \\
\hline Perdagangan & $\begin{array}{l}-0.084 \\
(0.069)\end{array}$ & $\begin{array}{l}-0.009^{* *} \\
(0.032)\end{array}$ \\
\hline Tes $F$ & 44.65 & \\
\hline Tes $L M$ & & 0.22 \\
\hline$R^{2}$ di dalam & 0.24 & \\
\hline$R^{2}$ di antara & 0.05 & \\
\hline$R^{2}$ Keseluruhan & 0.11 & \\
\hline Jumlah obs. & 168 & 168 \\
\hline Jumlah Negara & 8 & 8 \\
\hline \multicolumn{3}{|c|}{$\begin{array}{l}* * *,{ }^{* *} \text { dan } * \text { are signifikan pada level } 1 \%, 5 \% \text { and } 10 \% \text { secara berturut- } \\
\text { turut dan kesalahan pada standar cluster-robust diperlihatkan dalam } \\
\text { tanda kurung }\end{array}$} \\
\hline
\end{tabular}

Tes $F$ pada fixed effects menolak dengan jelas nilai nol, menyamakan korelasi antara variabel penjelas dan efek heterogen pada kesalahan. Dengan kata lain, estimasi pada fixed effects ini menyajikan estimator yang jelas dan konsisten. Sebaliknya, tes Breusch-Pagan Lagrange Multiplier yang digunakan pada random effects tidaklah signifikan pada level $10 \%$ dangagaldalam menolak absennya efek individu yang sama besar. Ini menunjukkan tidak adanya efek-random effects. Hasilnya, estimasi random effects ini bias dan tidak konsisten.

\section{Pertumbuhan Ekonomi dan Krisis Keuangan}

Selanjutnya, diskusi pada makalah ini berlanjut ke dampak krisis keuangan pada pertumbuhan ekonomi di perekonomian Asia Timur. Seperti yang ditunjukkan pada metodologi, makalah ini menggunakan metode krisis dummy untuk mengukur dampak krisis keuangan pada perekonomian di Asia Timur. Krisis dummy pertama dilakukan pada Krisis Financial Asia Timur 1997. Dalam hal ini, meskipun krisis terjadi pada 1997, variabel dummy menggunakan nilai satu pada 1997-1998 dengan mempertimbangkan efek lagging pada krisis. Krisis dummy yang kedua dilakukan pada Krisis Keuangan Global 2008. Karena adanya efek tertinggal (lagging), krisis buatan juga diterapkan ketika krisis terjadi dan pada tahun selanjutnya, misalnya 2008-2009. 
Tabel 2 menunjukkan model pertumbuhan acuan yang dikembangkan dengan memasukkan krisis dummy. Pada dua kolom pertama, model ini dikembangkan dengan Krisis Keuangan Asia Timur 1997. Secara umum, hubungan antara determinan pertumbuhan dan pertumbuhan pendapatan konsisten terhadap regresi standar awal. Selanjutnya, seperti yang telah diprediksi, krisis dummy berperan signifikan pada kedua model dengan nilai yang relatif sama. Berdasarkan estimasi, dibawah ceteris paribus, keberadaan Krisis Keuangan Asia Timur menyebabkan perekonomian Asia Timur mengalami pertumbuhan pendapatan yang negatif, sekitar6\%.

Sekali lagi, makalah ini menguji manakah di antara metode estimasi ini yang menyajikan estimasi yang lebih baik dengan melihat tes $F$ (untuk fixed effects) dan tes LM (untuk random effects). Sejalan dengan output dari regresi acuan, tes $F$ secara sifnifikan menolak nilai nol pada level $1 \%$, dimana tes LM gagal menolak nilai nolpada level 10\%. Sehingga, pada Krisis Keuangan Asia Timur, estimasi dari fixed effects merupakan model yang lebih baik karena estimator yang konsisten dan jelas di dalamnya.

\begin{tabular}{|c|c|c|c|c|}
\hline \multicolumn{5}{|c|}{$\begin{array}{l}\text { Tabel } 2 . \\
\text { Pertumbuhan Ekonomi dan Krisis Keuangan }\end{array}$} \\
\hline Variabel & Fixed effects & Random effects & Fixed effects & Random effects \\
\hline Konstan & $\begin{array}{l}-7.970 \\
(6.816)\end{array}$ & $\begin{array}{l}-0.435 \\
(1.921)\end{array}$ & $\begin{array}{l}-24.975^{\star *} \\
(10.310)\end{array}$ & $\begin{array}{l}-1.071 \\
(2.104)\end{array}$ \\
\hline Pendapatan & $\begin{array}{c}0.621 \\
(1.957)\end{array}$ & $\begin{array}{l}-1.359^{* * *} \\
(0.422)\end{array}$ & $\begin{array}{l}6.491^{*} \\
(3.270)\end{array}$ & $\begin{array}{l}-1.223^{* * *} \\
(0.405)\end{array}$ \\
\hline Modal & $\begin{array}{c}0.295^{* * *} \\
(0.051)\end{array}$ & $\begin{array}{l}0.311^{* * *} \\
(0.037)\end{array}$ & $\begin{array}{l}0.180^{*} \\
(0.085)\end{array}$ & $\begin{array}{l}0.307^{* * *} \\
(0.054)\end{array}$ \\
\hline FDI & $\begin{array}{l}0.428^{* * *} \\
(0.060)\end{array}$ & $\begin{array}{l}0.210^{* * *} \\
(0.042)\end{array}$ & $\begin{array}{l}0.328^{* *} \\
(0.104)\end{array}$ & $\begin{array}{l}0.171^{* * *} \\
(0.041)\end{array}$ \\
\hline Perdagangan & $\begin{array}{c}0.018 \\
(0.049)\end{array}$ & $\begin{array}{c}0.001 \\
(0.017)\end{array}$ & $\begin{array}{l}-0.119 \\
(0.079)\end{array}$ & $\begin{array}{c}0.004 \\
(0.028)\end{array}$ \\
\hline Krisis Asia & $\begin{array}{l}-5.944^{* * *} \\
(1.385)\end{array}$ & $\begin{array}{l}-5.988^{* * *} \\
(1.304)\end{array}$ & - & - \\
\hline Krisis Global & - & - & $\begin{array}{r}-3.014^{* *} \\
(0.945)\end{array}$ & $\begin{array}{l}-2.128^{* *} \\
(0.879)\end{array}$ \\
\hline Tes $F$ & 219.49 & & 89.48 & \\
\hline Tes $L M$ & & 0.00 & & 0.21 \\
\hline$R^{2}$ di dalam & 0.47 & & 0.296 & \\
\hline$R^{2}$ di antara & 0.40 & & 0.016 & \\
\hline$R^{2}$ Keseluruhan & 0.42 & & 0.020 & \\
\hline Jumlah obs. & 168 & 168 & 168 & 168 \\
\hline Jumlah Negara & 8 & 8 & 8 & 8 \\
\hline
\end{tabular}


Dua kolom terakhir menunjukkan model pertumbuhan acuan pada Krisis Keuangan Global 2008. Secara mengejutkan, model fixed effects menunjukkan bahwa nilai pendapatan meningkat jika model digunakan untuk krisis 2008, hal ini menunjukkan bahwa negara dengan pendapatan yang lebih besar cenderung untuk tumbuh lebih cepat meskipun tandanya sangat lemah (misalnya hanya signifikan pada level kepercayaan 10\%). Satu penjelasan yang mungkin adalah karena negara-negara dengan pendapatan yang relatif tinggi, terutama Singapura, berhasil mencapai pertumbuhan pendapatan di atas $10 \%$ setelah krisis meskipun pertumbuhan yang terjadi adalah pertumbuhan negatif ketika terjadi krisis, sedangkan negara-negara dengan pendapatan relatif rendah seperti Indonesia hanya mencapai pertumbuhan yang stabil meskipun negara-negara ini mampu menghindari pertumbuhan yang negatif ketika krisis terjadi.

Sebaliknya, variabel lain, seperti modal, FDI dan perdagangan, tidak membuat perbedaan yang signifikan dari estimasi sebelumnya. Akhirnya, dummy Krisis Keuangan Global ini signifikan pada level 5\% pada kedua regresi meskipun dampak krisisnya lebih tinggi pada model fixed effects. Selain itu, hasil dari model ini juga konsisten dengan ekspektasi dari makalah ini, sebagai contoh Krisis Keuangan Global 2008 memiliki dampak berlawanan yang lebih kecil dari pertumbuhan pendapatan pada perekonomian Asia Timur.

\section{Diskusi dan Analisis Lanjutan}

Selain koefisien untuk pendapatan dan perdagangan, hasil estimasi pada model ini sejalan dengan ekpektasi dan konsisten terhadap kajian sebelumnya. Tujuan dari bagian ini adalah untuk menunjukkan diskusi dan analisis lanjutan pada hasil estimasi. Pertama, koefisien pendapatan pada model acuan dan model yang telah ditambahkan dengan dummy Krisis Asia Timur 1997 menunjukkan hasil yang tidak signifikan dengan tanda-tanda yang tidak sejalan dengan ekspektasi. Akan tetapi, hasil estimasi dari model yang dikembangkan oleh dummy Krisis Keuangan Global 2008 signifikan pada level 10\% dan sama dengan kasus sebelumnya. Hasil ini menunjukkan bahwa mdoel pertumbuhan yang digunakan pada makalah ini sedikit mendukung teori pertumbuhan non-klasik Solow (1956), terutama yang berhubungan dengan konvergensi ekonomi.

Kedua, koefisien yang diestimasikan untuk modal seluruhnya signifikan dan positif seperti yang diperkirakan. Hal ini menunjukkan bahwa akumulasi modal memang berakibat positif pada pertumbuhan ekonomi. Namun, hasil estimasi untuk FDI, yang lebih signifikan dari hasil estimasi modal, menunjukkan adanya transfer pengetahuan dari perekonomian yang lebih maju ke perekonomian yang kurang maju melalui FDI. Hasil ini mendukung studi yang dilakukan oleh Lim (2001) dan Yao dan Wei (2007), yang menyatakan bahwa FDI mendukung eksternalitas dan efek tidak langsung yang akan meningkatkan efisiensi dari produktivitas perusahaan lokal. Sehingga, hal ini akan mendukung pertumbuhan ekonomi. 
Ketiga, koefisien yang diestimasikan untuk perdagangan seluruhnya tidak signifikan dan menunjukkan tanda-tanda yang berlawanan. Ini menunjukkan bahwa model ini menyajikan tanda-tanda yang tidak cukup bagi kita untuk menarik kesimpulan mengenai korelasi antara keterbukaan perdagangan dan pertumbuhan pendapatan. Meskipun begitu, hasil ini menunjukkan bahwa data yang digunakan pada makalah ini mendukung studi yang dilakukan oleh Chongvilaivan (2010), dimana makalahnya mengajukan bahwa variabel perdagangan tidak signifikan sebagai hasil dari adanya trade creation (penciptaan perdagangan) dan trade diversion (pengalihan perdagangan). Oleh karena itu, efek perdagangan pada pertumbuhan pendapatan bergantung pada keadaan apakah kesejahteraan anggota aliansi perdagangan meningkat pada pengeluaran nonanggota atau tidak.

Terakhir, meskipun kedua hasil estimasi untuk krisis dummy menunjukkan tanda negatif, dummy Krisis Asia Timur 1997 menunjukkan nilai yang lebih tinggi dibanding dummy Krisis Keuangan Global 2008. Hal ini sejalan dengan ekspektasi karena Krisis Asia Timur 1997 terjadi di wilayah Asia Timur dan merupakan hasil dari sebab-sebab internal wilayah tersebut, termasuk: 1) kurangnya kredibilitas kebijakan dan 2) infrastruktur keuangan yang tidak memadai, yang terjadi bersamaan dengan deregulasi keuangan. Sebab pertama, seperti yang dikemukakan oleh Rraisah (2001), adalah karena krisis ini awalnya didorong oleh penyalahgunaan intervensi negara dan kebijakan industri yang kurang efektif di wilayah tersebut. Sedangkan sebab kedua, deregulasi keuangan, infrastruktur keuangan yang tidak memadai, dan pengawasan perbankan yang lemah mendorong investasi yang beresiko tanpa pengkajian resiko yang cukup mengakibatkan gelembung pada kredit dan kolaps pada sektor keuangan (sebagai contoh, lihat Radelet dan Sachs, 2000). Faktor penting ekonomi yang lemah ini menunjukkan "kelemaham keuangan" sebagai isu utama dalam perekonomian Asia Timur, yang menyebabkan krisis pada 1997 dan menimpa perekonomian di wilayah ini dengan sangat buruk (lihat Lampiran 5 untuk statistik pada variabel makroekonomi selama dua krisis keuangan). Selanjutnya, krisis ini menjadi lebih mendalam karena perluasan yang terjadi di sektor riil, yang menimpa bisnis peminjam dan aliran modal yang besar.

Di lain pihak, krisis pada 2008 mengakibatkan dampak yang lebih kecil pada perekonomian wilayah tersebut karena wilayah tersebut hanya mengalami "efek menular" dari krisis yang sebenarnya berasal dari perekonomian yang telah maju. Untuk beberapa kasus, hasil ini mendukung makalah ini, yang menunjukkan bahwa divergensi (perbedaan) mungkin berhubungan dengan eksternalitas pada krisis keuangan global 2008. Krisis juga banyak ditujukan pada reformasi multidimensional yang mengikuti Krisis Keuangan Asia Timur 1997. Lebih jelasnya, Goldstein dan Xie (2009) menunjukkan bahwa besarnya kepemilikan pihak asing, meningkatnya struktur keuangan, tingginya kontribusi dari perdagangan regional, dan rasionalnya kebijakan moneter "countercyclical" dan fiskal akan membantu wilayah untuk menghadapi dampak negatif dari krisis. 


\section{KESIMPULAN}

Sistem keuangan dunia, didukung oleh perkembangan teknologi informasi, telah memperkuat integrasi keuangan antarnegara di dunia. Selain kegunaannya dalam keadaan ini, integrasi keuangan juga telah menyebabkan krisis keuangan menyebar lebih mudah dan lebih cepat dan merusak perekonomian yang terhubung. Karena alasan ini, studi mengenai krisis keuangan telah menjadi lebih penting dari sebelum-sebelumnya. Dalam hal ini, tujuan dari studi ini adalah untuk lebih memahami sebab dan akibat dari krisis keuangan yang terjadi saat ini dengan menyediakan analisis yang komprehensif untuk menghindari terjadinya, atau setidaknya meminimalisasi dampak krisis keuangan di masa mendatang.

Studi ini telah mengungkap temuan-temuan penting mengenai dampak utama krisis keuangan di perekonomian Asia Timur. Pertama, studi ini telah menginvestigasi dampak dari Krisis Keuangan Asia Timur 1997 dan Krisis Keuangan Global 2008 dengan menggunakan pendekatan kuantitatif, misalnya regresi panel. Hasilnya menunjukkan bahwa meskipun kedua krisis memiliki efek yang berkebalikan pada perekonomian di wilayahnya, perekonomian Asia Timur telah menjadi lebih kuat selama krisis pada 2008 dibanding krisis pada 1997. Lebih lanjut, makalah ini menemukan bahwa dampak yang diperkecil dari krisis pada 2008 terjadi karena, selain sifat eksternalitas krisis, sebagian besar perekonomian di Asia Timur telah mengambil pelajaran setelah Krisis Keuangan Asia Timur 1997 dengan memperkuat fundamental ekonomi, didukung kredibilitas dan akuntabilitas pemerintah yang lebih baik.

Usaha-usaha terpadu untuk menstrukturisasi sektor perbankan dan keuangan oleh pemerintahan Asia Timur setelah Krisis Keuangan Asia Timur 1997 telah meningkatkan ketahanan terhadap krisis ekonomi. Pengawasan yang lebih baik pada sektor ini dimasukkan pada reformasi, berkebalikan dengan masa deregulasi dan penangguhan sebelumnya serta penggabungan institusi-institusi yang bermasalah secara keuangan. Modal juga dilibatkan untuk membantu masalah likuiditas. Selain reformasi di sektor perbankan dan keuangan, persyaratan lebih tinggi untuk transparansi perusahaan juga dibutuhkan untuk meningkatkan kredibilitas pada sektor swasta. Bersama-sama, reformasi-reformasi ini telah memperkuat fundamental ekonomi di negara-negara Asia Timur. Hal penting lain yang telah memperbaiki kesiapan negaranegara Asia Timur dalam menghadapi Krisis Keuangan Global 2008 adalah peningkatan devisa negara, yang membantu pemerintahan dalam mempertahankan kondisi ekonomi selama terjadinya krisis.

Selain temuan-temuannya, cakupan studi ini terbatas pada data dan analisis di level negara. Oleh karena itu, studi lebih lanjut sebaiknya lebih fokus pada analisis di level industri dan seharusnya difasilitasi oleh adanya data di level industri untuk memeriksa sensitivitas masingmasing industri dalam mengantisipasi krisis keuangan. Selain itu, hasil-hasil estimasi pada studi ini dapat ditingkatkan dengan menambahkan variabel interaksi antara krisis buatandan variabel independen lainnnya serta memperkenalkan estimasi GMM dalam memperkirakan model untuk mendapatkan persamaan-persamaan yang serentak dalam model. 


\section{DAFTAR PUSTAKA}

Asian Development Bank (ADB). (1999). Asian Development Outlook 1999, Manila: Asian Development Bank.

Azman-Saini, W.N.W., Law, S.H., \& Ahmad, A.H. (2010). FDI and economic growth: New evidence on the role of financial markets, Economic Letters, Vol. 107, pp. 211-213.

Barro, R.J. (2001). Economic growth in East Asia before and after the Financial Crisis, National Bureau of Economic Research Working Paper Series, No. 8330.

Bhagwati, J. (1994). Free trade: Old and new challenges, Economic Journal, Vol. 104, pp. 231 246.

Chongvilaivan, A. (2010). Global Financial Crisis and growth prospects in Asia-Pacific: A sectoral analysis, paper presented at The $26^{\text {th }}$ Conference of the American Committee for Asian Economic Studies, Kyoto, Japan, 5-6 March.

Corsetti, G., Pesenti, P., \&Roubini, N. (1999). What caused the Asian currency and financial crisis? Japan and the World Economy, Vol. 11, pp. 305-373.

Davis, E.P. (1994). Market liquidity risk, Kluwer Academic Publishers.

Davis, E.P. (2001). A typology of financial instability, Oesterreichsche National Bank Financial Stability Report 2, pp. 92-110.

Diamond, D., Dybvig, P. (1983). Bank runs, deposit insurance and liquidity, Journal of Political Economy, vol. 91, pp. 401-419.

Edison, H.J., Levine. R., Ricci, L., \& Sløk, T. (2002). International financial integration and economic growth, National Bureau of Economic Research Working Paper Series, No. 9164.

Emmers, R., Ravenhill, J. (2011), The Asian and global financial crises: consequences for East Asian regionalism, Contemporary Politics, Vol. 17 No. 2, pp. 133-149

Fisher, I. (1933). The debt deflation theory of great depressions, Econometrica, Vol. 1, pp. 337357.

Goldstein, M., \&Xie, D. (2009). US credit crisis and spillovers to Asia, Asian Economic Policy Review, Vol. 4, pp. 204-222.

Hadri, K.(2000). Testing for stationarity in heterogeneous panel data, The Econometrics Journal, Vol. 3, No. 2, pp. 148-161. 
Herring, J. (1999). Credit risk and financial instability, Oxford Review of Economic Policy, Vol. 15, No. 3, pp. 63-67.

Im, K.S., Pesaran, M. H. \& Shin, Y. (2003).Testing for unit roots in heterogeneous panels, Journal of Econometrics, Vol. 115, pp. 53-74.

Jomo, K.S. (2001). Growth after the Asian Crisis: What remains of the East Asian Model?, G24 Discussion Paper Series, No. 10.

Kawai, M., Newfarmer, R., \&Schmukler, S. L. (2003). Financial crises: Nine Lessons from Asia, Japan Ministry of Finance PRI Discussion Paper, No. 2003-5.

Khor, M. (1998). The economic crisis in East Asia: Causes, effects, lessons, Third World Network.

Kindleberger, C. P. (1978). Manias, panics and crashes, A history of financial crises. Basic Books, New York.

Levin, A., Lin, C.F. \& Chu, C. (2002). Unit roots tests in panel data: Asymptotic and finite sample properties, Journal of Econometrics, Vol. 108, pp. 1-24.

Lim, E.G. (2001).Determinants of, and the relation between, foreign direct investment and growth: A summary of the recent literature, IMF Working Paper, WP/01/175.

Lloyd, P.J., \&MacLaren, D. (2000).Openness and growth in East Asia after the Asian crisis, Journal of Asian Economics, Vol. 11, pp. 89-105.

Lucas, R.E. (1988). On the mechanism of economic development, Journal of Monetary Economics, Vol. 22, pp. 3-42.

Rasiah, R. (2001). Pre-crisis economic weaknesses and vulnerabilities. In: Jomo KS, ed. Malaysian Eclipse: Economic Crisis and Recovery, London: Zed Books, pp. 47-66.

Radelet, S. and Sachs, J. (2000). The onset of East Asian financial crisis, National Bureau of Economic Research, pp. 105-162.

Research Bank of Australia. (2012). About financial stability. Retrieved from http:// www.rba.gov.au/fin-stability/about.html on 7 December 2012.

Romer, P.M. (1986).Increasing return and long run growth, Journal of Political Economy, vol. 95, pp. 1002-1037.

(1990). Endogenous technological change, Journal of Political Economy, Vol. 98, no. 5, pt. 2 .

Siegel, D. (1997). The impact of computers on manufacturing productivity growth: A multipleindicators, multiple-causes approach, Review of Economics and Statistics, Vol. 79, pp. 6878.

Siegel, D. \&Griliches, Z. (1992).Purchased services, outsourcing, computers, and productivity in manufacturing, National Bureau of Economic Research Working Paper Series, No. 3678. 
Solow, R.M. (1956).A contribution to the theory of economic growth, Quarterly Journal of Economics, LXX, pp. 65-94.

Stopford, J., Strange, S., \&Henley, J. (1991). Rival States, Rival Firms: Competition for World Market Shares, Cambridge: Cambridge University Press.

Todaro, M. P, \& Smith, S. C. (2006).Economic Development, Addison Wesley, Boston.

Viner, J. (1950). The Custom Union Issue, New York: Carnegie Endowment for International Peace.

World Bank. (various issues). World Bank Indicator (http://data.worldbank.org/indicator/)

Yao, S. \& Wei, K. (2007). Economic growth in the presence of FDI: The perspective of newly industrialising economies, Journal of Comparative Economics, V ol. 35, pp. 211-234. 


\section{LAMPIRAN}

\begin{tabular}{|c|c|}
\hline \multicolumn{2}{|r|}{$\begin{array}{c}\text { Lampiran } 1 . \\
\text { Deskripsi Variabel }\end{array}$} \\
\hline Variabel & Deskripsi \\
\hline Pertumbuhan & $\begin{array}{l}\text { Persentasi tingkat pertumbuhan tahunan dari PDB per kapita berdasarkan nilai mata uang } \\
\text { lokal yang konstan. PDB per kapita adalah produk domestik bruto dibagi jumlah populasi } \\
\text { pada pertengahan tahun. PDB pada harga pembeli adalah jumlah dari nilai bruto ditambah } \\
\text { seluruh produsen ekonomi di wilayah tersebut ditambah pajak produk dan dikurangi subsidi } \\
\text { yang tidak dimasukkan dalam nilai produk. Nilai ini dihitung tanpa membuat potongan untuk } \\
\text { penyusutan aset yang siap digunakan atau untuk penipisan dan degradasi sumber daya } \\
\text { alam. (Ditunjukkan dalam \%). }\end{array}$ \\
\hline Pendapatan & $\begin{array}{l}\text { PDB per kapita adalah produk domestik dibagi jumlah populasi pada pertengahan tahun. } \\
\text { PDB pada harga pembeli adalah jumlah dari nilai bruto ditambah seluruh produsen ekonomi } \\
\text { di wilayah tersebut ditambah pajak produk dan dikurangi subsidi yang tidak dimasukkan } \\
\text { dalam nilai produk. Nilai ini dihitung tanpa membuat potongan untuk penyusutan aset yang } \\
\text { siap digunakan atau untuk penipisan dan degradasi sumber daya alam. (Ditunjukkan dalam } \\
\text { dolar Amerika yang konstan). }\end{array}$ \\
\hline Modal & $\begin{array}{l}\text { Pembentukan modal bruto (dulunya investasti bruto domestik) terdiri dari pengeluaran sebagai } \\
\text { tambahan dari aset ekonomi tertentu ditambah perubahan bersih pada level persediaan } \\
\text { (inventori). Aset tetap (fixed asset) termasuk perbaikan tanah (pagar, parit, saluran air, dan } \\
\text { sebagainya), tumbuhan, mesin, dan pembelian alat dan bahan; dan konstruksi jalan, rel, dan } \\
\text { sejenisnya, termasuk sekolah, perkantoran, rumah sakit, hunian pribadi, dan bangunan } \\
\text { komersil dan industri. Inventori adalah saham barang-barang oleh forma untuk memenuhi } \\
\text { fluktuasi yang sementara atau tak terduga dalam proses prosuksi atau penjualan, dan "bekerja } \\
\text { dalam proses". Berdasarkan SNA 1993, penerimaan bersih dari hal-hal yang berharga juga } \\
\text { dianggap sebagai pembentukan modal. (Ditunjukkan dalam \% PDB). }\end{array}$ \\
\hline FDI & $\begin{array}{l}\text { Foreign direct investment adalah pemasukan bersih dari investasi untuk memperoleh bunga } \\
\text { pengelolaan yang abadi (10 persen atau lebih dari voting saham) dalam suatu perusahaan } \\
\text { yang beroperasi dalam ekonomi, bukan dalam bidang investor. Nilai ini adalah jumlah dari } \\
\text { modal yang adil, reinvestasi pemasukan, modal jangka panjang lain, dan modal jangka pendek } \\
\text { sebagaimana ditunjukkan pada keseimbangan pembayaran. (Ditunjukkan dalam \% PDB). }\end{array}$ \\
\hline Keterbukaan Perdagangan & Rasio antara ekspor dan impor terhadap PDB (Ditunjukkan dalam \% PDB). \\
\hline Krisis & $\begin{array}{l}\text { Variabel buatan untuk menunjukkan terjadinya krisis (apakah Krisis Keuangan } 1997 \\
\text { atau Krisis Keuangan Global 2008). Variabel ini mengambil nilai kesatuan selama krisis } \\
\text { dan nilai nol selama masa non-krisis. }\end{array}$ \\
\hline
\end{tabular}

\begin{tabular}{|l|c|c|c|c|c|}
\hline \multicolumn{7}{|c|}{ Rampiran 2. } \\
\hline \multicolumn{1}{|c|}{ Rangkuman Statistik (Periode 1990-2010) } \\
\hline \multicolumn{1}{|c|}{ Variabel } & Obs. & Mean & S.D. & Min & Max \\
\hline Pertumbuhan & 357 & 2.843 & 3.567 & 14.287 & 13.605 \\
Pendapatan & 357 & 3.864 & 0.644 & 2.486 & 4.610 \\
Modal & 357 & 24.875 & 7.465 & 11.367 & 48.243 \\
FDI & 357 & 2.900 & 3.672 & 5.112 & 22.018 \\
Keterbukaan & 357 & 2.583 & 7.011 & 10.337 & 32.266 \\
Perdagangan & & & & & \\
\end{tabular}




\begin{tabular}{|c|c|c|c|c|}
\hline \multicolumn{5}{|c|}{$\begin{array}{l}\text { Lampiran } 3 . \\
\text { Korelasi Matriks dari Variabel Independen }\end{array}$} \\
\hline & Pendapatan & Modal & FDI & $\begin{array}{l}\text { Keterbukaan } \\
\text { Perdagangan }\end{array}$ \\
\hline Pendapatan & 1.000 & & & \\
\hline Modal & 0.166 & 1.000 & & \\
\hline FDI & 0.391 & 0.117 & 1.000 & \\
\hline Keterbukaan Perdagangan & 0.132 & 0.530 & 0.028 & 1.000 \\
\hline
\end{tabular}

\section{Lampiran 4.}

Tes Levin Lin Chui untuk akar unitpanel

\begin{tabular}{|c|c|c|c|}
\hline Variabel & t-star & Nilai t & Nilai $p$ \\
\hline Pertumbuhan & 8.871 & 4.869 & 0.000 \\
\hline Pendapatan & 7.941 & 2.717 & 0.003 \\
\hline Modal & 7.543 & 2.456 & 0.007 \\
\hline FDI & 10.362 & 4.292 & 0.000 \\
\hline Keterbukaan Perdagangan & 7.086 & 2.295 & 0.011 \\
\hline
\end{tabular}




\section{LAMPIRAN 5. STATISTIK MAKROEKONOMI LAIN}

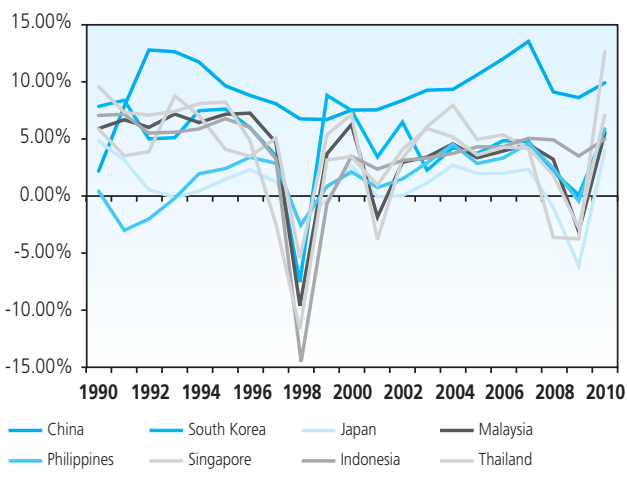

Source : World Bank's World Development Indicato

\section{Lampiran 5.1. PDB per kapita dalam perekonomian Asia Timur (tingkat pertumbuhan tahunan, \%)}

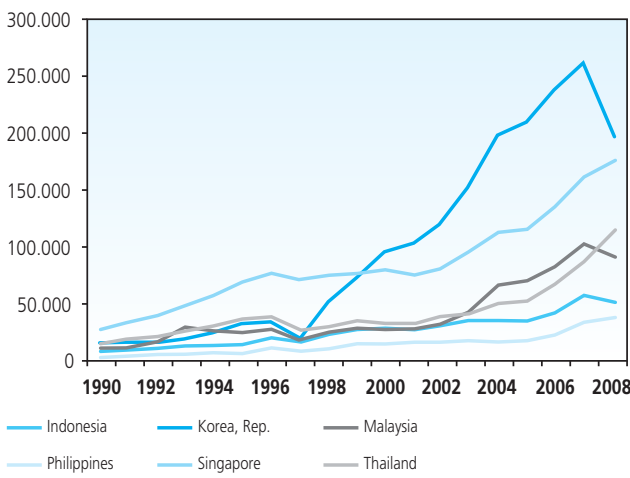

Source : World Bank's World Development Indicator and Global Development Finance.

Lampiran 5.2. Cadangan devisa dari beberapa negara Asia Timur (dalam jutaan) 


\begin{tabular}{l|c|c}
\multicolumn{2}{c}{ Lampiran 5.3. } \\
& \multicolumn{2}{|c}{ Inflasi } \\
\cline { 2 - 3 } & 1997 & 1998 \\
\hline \multirow{2}{*}{ China } & 2.8 & -0.8 \\
\hline Indonesia & 6.2 & 58.4 \\
\hline Jepang & 1.8 & 0.7 \\
\hline Malaysia & 2.7 & 5.3 \\
\hline Filipina & 5.6 & 9.3 \\
\hline Singapura & 2 & -0.3 \\
\hline Korea Selatan & 4.4 & 7.5 \\
\hline Thailand & 5.6 & 8.0 \\
\hline Sumber: World Bank's World Development Indicator
\end{tabular}

\begin{tabular}{|c|c|c|c|c|c|c|c|c|c|c|}
\hline \multicolumn{11}{|c|}{$\begin{array}{l}\text { Lampiran } 5.4 . \\
\text { Asia Timur Empat: Indikator Makroekonomi, 1990-1999 }\end{array}$} \\
\hline & \multicolumn{5}{|c|}{ Tingkat Pengangguran } & \multicolumn{5}{|c|}{ Tabungan / PDB } \\
\hline & 1990 & 1996 & 1997 & 1998 & 1999 & $1990-95$ & 1996 & 1997 & 1998 & 1999 \\
\hline Indonesia & n.a. & 4.1 & 4.6 & 5.5 & 6.3 & 31 & 26.2 & 26.4 & 26.1 & 23.7 \\
\hline Malaysia & 6 & 2.5 & 2.4 & 3.2 & 3 & 36.6 & 37.1 & 37.3 & 39.6 & 38 \\
\hline Rep. of Korea & 2.4 & 3 & 2.6 & 6.8 & 6.3 & 35.6 & 33.7 & 33.3 & 33.8 & 33.5 \\
\hline \multirow[t]{3}{*}{ Thailand } & 4.9 & 1.1 & 0.9 & 3.5 & 4.1 & 34.4 & 33 & 32.5 & 34.9 & 31 \\
\hline & \multicolumn{5}{|c|}{ Investasi / PDB } & \multicolumn{5}{|c|}{ (Tabungan-Investasi) / PDB } \\
\hline & $1990-95$ & 1996 & 1997 & 1998 & 1999 & $1990-95$ & 1996 & 1997 & 1998 & 1999 \\
\hline Indonesia & 31.3 & 29.6 & 28.7 & 22.1 & 19.3 & -0.3 & -3.4 & -2.3 & 4 & 4.4 \\
\hline Malaysia & 37.5 & 42.5 & 43.1 & 26.8 & 22.3 & -0.9 & -5.4 & -5.8 & 12.8 & 15.7 \\
\hline Rep. of Korea & 36.8 & 36.8 & 35.1 & 29.8 & 28 & -1.2 & -3.1 & -1.8 & 4.1 & 5.5 \\
\hline \multirow[t]{3}{*}{ Thailand } & 41 & 41.1 & 33.3 & 22.2 & 21 & -5.6 & -8.1 & -0.9 & 12.8 & 10 \\
\hline & \multicolumn{5}{|c|}{ Rasio tambahan modal-output } & & & & & \\
\hline & $1987-89$ & $1990-92$ & $1993-95$ & 1997 & 1998 & 1999 & & & & \\
\hline Indonesia & 4 & 3.9 & 4.4 & 1.7 & 0.4 & 1.8 & & & & \\
\hline Malaysia & 3.6 & 4.4 & 5 & 3.9 & 28.2 & 4.3 & & & & \\
\hline Rep. of Korea & 3.5 & 5.1 & 5.1 & 4.2 & -15.1 & 3.2 & & & & \\
\hline \multirow[t]{3}{*}{ Thailand } & 2.9 & 4.6 & 5.2 & 12.9 & -11.5 & 14.5 & & & & \\
\hline & \multicolumn{5}{|c|}{ Keseimbangan fiskal / PDB } & & & & & \\
\hline & $1990-95$ & 1996 & 1997 & 1998 & 1999 & & & & & \\
\hline Indonesia & 0.2 & 1.4 & 1.3 & -2.6 & -3.4 & & & & & \\
\hline Malaysia & -0.4 & 0.7 & 2.4 & -1.8 & -3.2 & & & & & \\
\hline Rep. of Korea & 0.2 & 0.5 & -1.4 & -4.2 & -2.9 & & & & & \\
\hline Thailand & 3.2 & 2.4 & -0.9 & -3.4 & -3 & & & & & \\
\hline \multicolumn{11}{|c|}{$\begin{array}{l}\text { Sumber: Radelet and Sachs (1998: table 11); ADB (1999); Bank of Thailand, } \\
\text { Bank Indonesia, Bank of Korea, Bank Negara Malaysia, quoted from Jomo } \\
\text { (2011). }\end{array}$} \\
\hline
\end{tabular}

